\title{
Publisher Correction to: Effect of light intensity and substrate type on siscowet lake trout (Salvelinus namaycush siscowet) predation on deepwater sculpin (Myoxocephalus thompsonii)
}

\author{
Trevor D. Keyl 1 - Thomas R. Hrabik - Allen F. Mensinger • Loranzie S. Rogers • \\ Owen T. Gorman
}

Published online: 11 May 2020

(C) Springer Nature Switzerland AG 2020

Publisher Correction to:

Hydrobiologia (2019) 840:77-88

https://doi.org/10.1007/s10750-019-3944-5

Due to a mistake during the production process, the online/HTML version of the original article was published under the terms of the Creative Commons
Attribution 4.0 International License. The article is not open access and no special license applies. The original article has been corrected.

Publisher's Note Springer Nature remains neutral with regard to jurisdictional claims in published maps and institutional affiliations.

The original article can be found online at https:// doi.org/10.1007/s10750-019-3944-5.

T. D. Keyl ( $)$

Biology Department, College of St. Benedict/St. John's University, Collegeville, MN 56321, USA

e-mail: tkeyler001@csbsju.edu

T. D. Keyl · T. R. Hrabik · A. F. Mensinger

L. S. Rogers

Biology Department, University of Minnesota, Duluth, MN 55812, USA

O. T. Gorman

U.S. Geological Survey, Lake Superior Biological Station, Ashland, WI 54806, USA 